\title{
Right to Environment and Right to Development: A Judicial Conundrum
}

\author{
Uday Shankar* and Saurabh Bindal ${ }^{* *}$
}

\begin{abstract}
Pollution free environment is indispensible for the inhabitants of this planet. The Supreme Court of India taking cognizance of the same in its judicial creativity has accorded the right to live in a pollution free environment the status of a fundamental right under Article 21 of the Constitution of India. At the same time, right to development places human beings at the centre of development casting an obligation on the state to ensure the benefits of development to the citizenry. Interestingly, both right to environment and right to development draw their genesis from Article 21 of the Constitution. Such affirmation of rights necessarily presents a question of compliance by the state. This paper traces the origin of right to environment and right to development in the larger context of the fundamental rights. It critically examines the usefulness of declaration of these rights under the scheme of the Constitution. It argues that the judiciary in its judicial creativity has made unreasonable interference into the matters reserved for the executive which is not in accordance with the basic structure of the Constitution. The paper calls for maintenance of harmony between the two organs of the state.
\end{abstract}

Keywords: Development, Environment, Fundamental Rights, Individual Interest, Societal Interest.

\footnotetext{
* Assistant Professor of Law, Rajiv Gandhi School of Intellectual Property Law, IIT, Kharagpur, West Bengal.

** Final Year, Rajiv Gandhi School of Intellectual Property Law, IIT, Kharagpur, West Bengal.
} 


\section{Overture}

Clean and healthy environment is a prerequisite for existence of human civilization. It is indispensible for the holistic growth of the society. Clean and healthy environment has been the focal point of deliberations since time immemorial. Human rights constitute inviolable interest of an individual which are non-negotiable. Inalienable interests of individual, which guarantee autonomy and well-being, provide content to human rights. ${ }^{1}$ The discourse of human rights builds upon the values of dignity which are inseparable and which cannot be traded-off. Generations after generations have debated upon the place of right to environment in the discourse of human rights.

Traditional content of rights revolves around values of liberty and autonomy of individuals which was later infused with socioeconomic interest of an individual. Increase of the content of rights raises serious concern regarding obligations of the state to fulfill these rights. On the one hand, the addition in the content raises the standards of human values and on the other hand, it creates serious apprehensions regarding implementation of newly created or established rights. ${ }^{2}$

Likewise, the Supreme Court of India has depicted judicial creativity by introducing new set of rights in the chapter of fundamental rights under the Constitution which is made enforceable in the court of law. Amongst many, right to clean and healthy environment is one such right which has attained the status of fundamental rights through judicial innovation. In its creative role, the judiciary has also constructed right to development as a fundamental right. Right to development places human being at the centre of development wherein the state is under an obligation to ensure benefits of development to individual.

${ }^{1}$ Dadwal, L., Position of Human Rights: An Indian Profile, 39 C.M.L.J. 221, 225 (2003).

2 Dr. Adarsh Sein Anand, Former Chief Justice of India, Inaugural Speech at the Golden Jubilee Celebration of the Rajasthan High Court (Aug. 29, 1999) ("there exist a danger by creating multiplicity of rights without possibility of adequate enforcement"). 
Interestingly, both right to environment and right to development draw their genesis from Article 21 of the Constitution of India. Right to environment also lends support from the reading of Article $48 \mathrm{~A}^{3}$ which is in the nature of the Directive Principles of State of Policy.

It is noteworthy to mention that the nature of rights and their enforceability raises the question of implementation of these rights on the ground that these rights fall within the domain of socioeconomic rights, which require different implementation mechanism than traditional human rights. The nature of the rights play an important role in fulfilling the obligation of state. If judicial pronouncements are not viable to compliance, then it threatens the institutional legitimacy of the judiciary. The judiciary needs to tread on a cautious path which intersects with political realm. It is not an exaggeration to state that such judicial declaration may damage the discourse of rights instead of strengthening the debate.

\section{Prelude}

Lavasa, ${ }^{4}$ Vedanta ${ }^{5}$ and Posco $^{6}$ remind us of the environmental disputes, which have been the cynosure of all eyes for the past two years. Development vis-à-vis environment has been on the placard

\footnotetext{
${ }^{3}$ THE CONSTITUTION OF INDIA, art. 48A.

${ }^{4}$ Lavasa case: Pune court summons 15 accused, CNBC-TV18 (Nov. 24, 2011), http://www.moneycontrol.com/news/current-affairs/lavasa-case-punecourt-summons-15-accused_623722.html.

${ }^{5}$ Ravi Ananthanarayanan, Vedanta case is a wake-up call, LiveMinT (Aug. $25,2010)$,
}

http:/ / www.livemint.com/2010/08/25230413/Vedanta-case-is-awakeup-call.html.

${ }^{6}$ Matthias Williams, Fight over land turns Posco plant into a test case of India's investment climate, DNA (Jun. 25, 2011), http:// www.dnaindia.com/ money/report_fight-over-land-turns-posco-plant-into-a-test-case-of-indias-investment-climate_1558778. 
of all the concerned stakeholders. ${ }^{7}$ These disputes do not only portray a picture where development conflicts with environment, they also represent the clash of societal interest with individual interests. ${ }^{8} \mathrm{~A}$ wider reading of the debate between development and environment presents a hitherto unknown canvass wherein the Indian courts have tried to sprinkle the balancing colours of societal interest and the individualistic interest. ${ }^{9}$ It is pertinent to note that Indian courts have read right to development and right to environment under Article 21 of the Constitution of India. Right to healthy environment represents a societal interest which is enshrined in the Directive principles of State Policy under the Constitution of India. Heretofore, Indian Courts have walked on a tight rope when it comes to balancing the Directive Principles of State Policy with the fundamental rights embodied in the Constitution. ${ }^{10}$ In recent years, they have read the socio-economic rights, enshrined in the Directives, under the banner of fundamental rights. ${ }^{11}$ This overzealous approach has not only

7 Subin Nijhawan, A Human Right to a Clean Environment, School of Oriental and African Studies, London, Faculty of Law and Social Sciences, Centre for International Studies and Diplomacy (Feb. 20, 2004); see also Geetanjoy Sahu, 'Implications of Indian Supreme Court's Innovations for Environmental Jurisprudence', 4/1 LAW, ENVIRONMENT AND DEVELOPMENT JOURNAL 1 (2008).

8 Samatha v. State of Andhra Pradesh, A.I.R. 1997 S.C. 3297 (establishing that fundamental rights address individual's interest whereas the Directive Principles of State Policy address societal concerns).

9 M.R.Anderson, Individual Rights to Environmental Protection in India, in Human Rights Approaches to Environmental Protection (A. E. Boyle and M.R. Anderson eds., Oxford University Press 1998).

10 S.P. Sathe, Post Emergency Judicial Activism: Liberty and Good Governance, 10 (4) JOURNAL OF INDIAN SCHOOL OF POLITICAL ECONOMY 603 (1998).

11 J. P. Unnikrishnan v. State of Andhra Pradesh, (1993) 1 S.C.C. 645; see also M. C. Mehta v. Union of India, A.I.R. 1987 S.C. 1086; Rural Litigation and Entitlement Kendra v. State of Uttar Pradesh, 1987 Supp. S.C.C. 487; Subash Kumar v. Union of India, (1991) 1 S.C.C. 598; N. D. Jayal v. Union of India, (2004) 9 S.C.C. 362; M. C. Mehta v. Union of India, (2006) 3 S.C.C. 399; Pt. Parmanand Katara v. Union of India, A.I.R. 1989 S.C. 2039; Shantisar Builders v. N. K. Totame, A.I.R. 1990 S.C. 5151; Gauri Shankar v. 
yielded in judicial activism ${ }^{12}$ but also has resulted in assisting executives in shirking their responsibilities. Fundamental rights represent individualistic freedoms, whereas the directives represent societal interests. The former provide negative rights, whereas the latter vouch for positive rights. When the court reads one interest under the banner of other, in the process of balancing the two competing interests, ${ }^{13}$ it moves away from the principle of harmonious construction. ${ }^{14}$ To divulgate over the scholarly writings on right to development and right to environment is not the theme of this paper. Instead, this paper argues that both right to development and right to environment cannot be read under the umbrella of the fundamental rights. Indian courts are not entrusted with the duty of enforcing Directive Principles of State Policy. ${ }^{15}$ Such being the case, the courts should tread punctiliously on the prescribed path laid for the legislature and the executive. Right to development and right to healthy environment, both being part of the Directive Principles of State Policy, call for a different approach towards their realization. These human rights are so essential for the well being of an individual, and society as a whole, that their enforcement was entrusted by the framers of the Constitution of

Union of India, (1994) 6 S.C.C. 349; Shiv Sagar Tiwari v. Union of India, (1997) 1 S.C.C. 444; Chameli Singh v. State of Uttar Pradesh, (1996) 2 S.C.C. 549; J. P. Ravidas v. Nav Yuvak Harijan Uttapam Society Ltd., (1996) 9 S.C.C. 300; Gaurav Jain v. Union of India, (1997) 8 S.C.C. 114; State of Bihar v. L K Advani, (2003) 8 S.C.C. 361.

12 S.S. Prakash and P.V.N. Sharma, Environment Protection vis-a-vis Judicial Activism, 2 S.C.J. 56 (1998).

13 M.C Mehta v. Union of India, (2004) 12 S.C.C. 118 ("deforestation has caused ecological imbalance and it has become a social menace which should be prevented. Obligation to society must predominate over obligation to individual").

14 State of Kerala v. N. M. Thomas, A.I.R. 1976 S.C. 490 ("Keshvanand Bharti has clinched the issue of primacy as between Part III and Part IV of the Constitution. The unanimous ruling is that the Court must wisely read the collective Directive principles of State Policy mentioned in Part IV into individual fundamental rights of Part III, neither Part being superior to the other").

15 A.B.S.K.S. v. Union of India, A.I.R. 1981 S.C. 246. 
India to the state. ${ }^{16}$ The intention of our forefathers was to lay an effective tract, by which, the realization of the socio-economic needs of the society were to be guaranteed by the state. Judicial recourse for maintenance of societal interest provides a detrimental picturesque for the entire nation. ${ }^{17}$ Moreover, the principle of harmonious construction suffers from a setback whenever the judiciary reads the socio-economic interest of the society under the garb of the fundamental rights of an individual. The set back suffered is in the form of a blow to the societal interest, by subjugation of the same to the individualistic interests. By trying to balance one interest over the other, the Indian judiciary has heralded an obscure new chapter to the wider debate of realization of human rights under the jurisprudence of Article 21 of the Constitution. Article 21 cannot act as a hinge for donning both individualistic and societal freedoms. This judicial conundrum can only be solved by enjoining the state to address the issues pertaining to both right to development and right to environment. Involvement of judiciary has only resulted in trade-off and the elusive quest for the right balance has acted as a stumbling block for the whole human rights jurisprudence. If at all the judiciary is willing to untie the Gordian Knot for the jurisprudence of environmental law, it has to do it by reading both the Directive principles and the Fundamental rights on the same page.

Directive Principles of the State Policy as laid down under the Constitution represents the aspirations and hopes of millions, the realization of which is to be undertaken by the state. The percussion of socio-economic rights gets its sound from the said principles, which majorly represent the scheme of development of a healthy society. These principles are unenforceable in court of law. 18 The duty of their enforcement was given specifically to the state because effective realization of the hope of millions can only

${ }^{16}$ H.R.KHANNA, MAKING OF INDIA'S CONSTITUTION (2nd ed. 2009).

17 Jamie Cassels, Judicial Activism and Public Interest Litigation in India: Attempting the Impossible?, in 37(3) THE AMERICAN JOURNAL OF COMPARATIVE LAW 495 (1989).

18 THE CONSTITUTION OF INDIA, art. 37. 
be achieved by undertaking a holistic approach towards society. ${ }^{19}$ The destination of cherished dreams for "we the people" can only be approached by walking each rung in the ladder diligently. This diligence can be attained only by the state, by undertaking the duties assigned to it. The cushion which the Indian judiciary is aiming to provide is far from acting as a leap for the development of the society. Reading right to development and right to environment under the ambit of fundamental rights casts a negative duty on the State. This is not what was intended by the framers of the Constitution. The flawed approach followed by the Indian judiciary is against the theory of separation of power, which is inscribed in our Constitution as the ribbon, tying the whole "Sovereign, Socialist, Secular, Democratic, Republic" together.

\section{Right to Environment under the Constitution}

Article 21 of the Constitution of India stands as the vanguard of freedoms related to life $^{20}$ and personal liberty. ${ }^{21}$ To any civilized society, there can be no attributes more important than the life and personal liberty of its members. ${ }^{22}$ Life as enshrined in Article 21 has received an expansive interpretation in the hands of judiciary. Some of the rights, not expressly mentioned as fundamental rights have been raised to the status of fundamental rights by the judiciary.

In Chameli Singh v. State of U.P. ${ }^{23}$ the court said that "right to live in any civilized society implies the right to food, water, decent environment, education, medical care and shelter. These are basic human rights known to any civilized society. All civil, political, social and cultural rights enshrined in the Universal Declaration of

${ }^{19}$ I.R. Coelho v. State of T.N., (2007) 2 S.C.C. 1.

${ }^{20}$ Shantistar Builders v. Narayan, (1990) 1 S.C.C. 520 ("right to life will take within its sweep, the right to food, clothing, decent environment and reasonable accommodation to live in").

21 The CONSTITUTION OF INDIA, art. 21.

22 Kehar Singh v. Union of India, (1989) 1 S.C.C. 204.

23 (1996) 2 S.C.C. 549. 
Human Rights, 1948 or the ones guaranteed under the Constitution of India cannot be exercised without these basic human rights." The freedom guaranteed under Article 21 is available to a person against the state. An aggrieved person can take ultimate recourse for the violation of Article 21 under Article 32 and Article 226 of the Constitution of India. ${ }^{24}$

The freedoms guaranteed under Article 21 are not absolute. The right to life, under the protection of Article 21, has been given an expansive interpretation to include the human rights jurisprudence under its ambit. ${ }^{25}$ In Sodan Singh v. N.D.M.C. ${ }^{26}$ the Supreme Court had held that "in view of the global development in the sphere of human rights these judicial decisions are a strong pointer towards the recognition of an affirmative right to the basic necessities of life under Article 21." In Francis Coralie v. Union Territory of Delhi27 the court held that the right to life includes the right to live with dignity. In Unni Krishnan v. State of A.P. ${ }^{28}$ the court said that "if Article 21, which is the heart of fundamental rights, has received expanded meaning from time to time there is no justification as to why it cannot be interpreted in the light of Directive Principles." Right to environment, inscribed as a guideline under Article $48 \mathrm{~A}$ of the Constitution, has been read under Article 21 of the

${ }^{24}$ L.K.Koolwal v. State of Rajasthan, A.I.R. 1988 Raj. 2 ("maintenance of health, sanitation and environment falls within Art.21 thus rendering the citizens the fundamental right to ask for affirmative action").

${ }^{25}$ Sunil Batra(II) v. Delhi Administration, (1980) 3 S.C.C. 488 ("today human rights jurisprudence in India has a constitutional status and sweep by virtue of Article 21 so that this magna carta may well toll the knell of human bondage beyond civilized limits").

26 (1989) 4 S.C.C. 155.

27 A.I.R. 1981 S.C. 746 ("we think that the right to life includes the right to live with human dignity and all that goes along with it, namely, the bare necessities of life such as adequate nutrition, clothing and shelter over the head and facilities for reading, writing and expressing oneself in diverse forms, freely moving about and mixing and commingling with fellow human beings").

28 (1993) 1 S.C.C. 645. 
Constitution by the Indian courts as a human right. ${ }^{29}$ The entire environmental law jurisprudence has evolved under the shroud of Article 21 of the Constitution of India. ${ }^{30}$ Right to life enshrined in Article 21 means right to have something more than survival and not mere existence or animal existence. ${ }^{31}$ Health hazards, due to pollution, have also been brought within its extended meaning. ${ }^{32}$ Indian Supreme Court has said that any disturbance of the basic environment elements, namely, air, water and soil, which are necessary for "life", would be hazardous to "life" within the meaning of Article 21.33 Right to water has also been recognized as a part of right to life. ${ }^{34}$

Indian Supreme Court, while recognizing the role of the Supreme Court in providing healthy environment, in T.N Godavarman

29 Subhash Kumar v. State of Bihar, A.I.R. 1991 S.C. 420 ("the right to life enshrined in Art. 21 includes the right to enjoyment of pollution free water and air for the full enjoyment of life. If anything endangers or impairs the quality of life, an affected person or a person genuinely interested in the protection of society would have recourse to Art. 32").

${ }^{30}$ Damodhar Rao v. Municipal Corporation, Hyderabad, A.I.R. 1987 A.P. 170 ("there can be no reason why practice of violent extinguishments of life alone would be regarded as violative of Art.21 of Constitution. The slow poisoning by the polluted atmosphere caused by environmental pollution and spoilation should also be regarded as amounting to violation of Art.21 of the Constitution").

31 Virendra Gaur v. State of Haryana, 19952 S.C.C. 577.

32 Ashok v. Union of India, (1997) 5 S.C.C. 10; see also Samatha v. State of A.P., A.I.R 1997 S.C. 3297; M.C. Mehta v. Union of India, (1999) 6 S.C.C. 9; M.C. Mehta v. Union of India (1996) 4 S.C.C. 351; M.C. Mehta v. Union of India, (2002) 10 S.C.C. 191; M.C. Mehta v. Union of India, (2001) 3 S.C.C. 756.

${ }^{33}$ M.C. Mehta v. Kamal Nath, (2000) 6 S.C.C. 213; see also Virender Gaur v. State of Haryana, (1995) 2 S.C.C. 577; A.P. Pollution Control Board v. M.V. Nayudu, (1999) 2 S.C.C. 718.

${ }^{34}$ M.K. Balakrishnan v. Union of India, (2009) 5 S.C.C. 511 ("right to water is a part of right to life guaranteed by Article 21"); see also State of Orissa v. Govt. of India, (2009) 5 S.C.C. 492; Delhi Water Supply and Sewage Disposal Undertaking v. State of Haryana, (1996) 2 S.C.C. 572. 
Thirumulpad $v$. Union of India 35 has said that "natural resources are the assets of the entire nation. It is the obligation of all concerned, including the union government and the state governments to conserve and not to waste the resources. Any threat to ecology can lead to violation of the right of enjoyment of healthy life guaranteed under Article 21, which is required to be protected. The Constitution enjoins upon the Supreme Court a duty to protect the environment." On the other hand, giving credence to the role of state, the Supreme Court in Vincent Panikurlangara v. Union of India ${ }^{36}$ has said that "a healthy body is the very foundation for all human activities. In a welfare state it is the obligation of the state to ensure the creation and the sustenance of conditions, congenial to good health." This was also reiterated in Delhi Transport Dept. Re. ${ }^{37}$ Recognizing the importance of both, state action and indulgence by the Supreme Court, in Research Foundation v. Union of India ${ }^{38}$ the court said that "the right to information and community participation necessary for protection of environment and human health is an inalienable part of Article 21 and is governed by the accepted environmental principles. The government and the authorities have to motivate public participation by formulating the necessary programmes." This approach was reiterated in Goa Foundation $v$. Union of India, ${ }^{39}$ wherein the court said that "government of India is not powerless to ensure compliance with

35 (2006) 1 SCC 1 ("entitlement to clean environment is one of the recognised basic human rights. The right to life inherent in Article 21 of the Constitution of India does not fall short of the required quality of life which is possible only in an environment of quality."); see also V. Lakshmipathy v. State of Karnataka, A.I.R. 1992 Kant. 57 ("where on account of human agencies, the quality of air and quality of environment are threatened or affected, the Court would not hesitate to use its innovative power to enforce and safeguard the right to life to promote public interest.").

36 (1987) 2 S.C.C. 165.

37 (1998) 9 S.C.C. 250 (" the state government is under a constitutional obligation to control pollution and if necessary by anticipating the causes of pollution and curbing the same.").

38 (2005) 10 S.C.C. 510.

39 (2005) 11 S.C.C. 560. 
environmental laws in particular the Environment Protection Act, 1986. Government is directed to issue order for closure of defaulting units who continue to operate in violation of environmental laws.

In the same vein, right to development has been read by the judiciary as a part of Article 21 of the Constitution of India. Human right to development bases its premise on both the fundamental rights and Directive Principles of State Policy. Fundamental rights and the Directives, both form two wheels of the chariot of development. Elucidating on the right to development, the Indian Supreme Court in Samatha v. State of A.P. ${ }^{40}$ said that "India being an active participant in the successful Declaration on Right to Development, 1986 and a party signatory thereto, it is its duty to formulate policies, legislative or executive, and to protect the social, economic, civil and cultural rights of the people, in particular, the poor, the Dalits and Tribes as enjoined in Article 46 read with Arts. 38 and 39 of the Constitution. By that constant endeavour and interaction, right to life would become meaningful so as to realise its full potentiality as an inalienable human right. Social and economic democracy is the foundation on which political democracy would be a way of life in the Indian polity. Law as a means of social engineering has to create just social order by removing inequalities in social and economic life." In N.D. Jayal and Anr. v. Union of India, ${ }^{41}$ the second Tehri Dam case, the Supreme Court said that "the right to development cannot be treated as a mere right to economic betterment or cannot be limited to as a misnomer to simple construction activities. Right to development encompasses much more than economic well being, and includes within its definition the guarantee of fundamental human rights. The right to development includes the whole spectrum of civil, cultural, economic, political and social process, for the improvement of peoples' well being and realization of their full potential. It is an integral part of human right. Of course, construction of a dam or a mega project is definitely an attempt to

\footnotetext{
40 A.I.R. 1997 S.C. 3297.

41 (2004) 9 S.C.C. 362.
} 
achieve the goal of wholesome development. Such works could very well be treated as integral component of development."

\section{Right to Development vis-à-vis Right to Environment}

The era of pro-environmental adjudications start from Rural Litigation $\mathcal{E}$ Entitlement Kendra v. Union of India ${ }^{42}$. In this case, the Indian Supreme Court while reading development vis-à-vis right to environment said that "the consequence of this order made by us would be that the lessees of lime stone quarries which have been directed to be closed down permanently, after consideration of the report of the Bandyopadhyay Committee, would be thrown out of business in which they have invested large sums of money and expanded considerable time and effort. This would undoubtedly cause hardship to them but it is a price that has to be paid for protecting and safeguarding the right of the people to live in healthy environment with minimal disturbance of ecological balance and without avoidable hazard to them and to their cattle, homes and agricultural land and undue contamination of air, water and environment." 43 Court in the said case ordered the closure of lime stone quarries and further directed the state to set up the monitoring committee to look after re-afforestation, mining activities and all other aspects necessary to bring about natural normalcy in the Doon Valley. The court also issued directions regarding the finances, powers and duties of the Monitoring Committee. Similarly in Ambica Quarry Works v. State of Gujarat and Others, ${ }^{44}$ the two appeals centered around the question as to how to strike balance between the need of exploitation of the mineral resources lying hidden in the forests and the need for preservation of the ecological balance thereby arresting the growing environmental deterioration. The Supreme Court in the said case took a stance towards the protection of environment and observed that in this case the renewal of the mining leases will lead to further deforestation or at least will not help reclaiming the areas where

\footnotetext{
421989 S.C.C. Supp. (1) 537.

${ }^{43} \mathrm{Id}$. at 656.
}

44 1987 S.C.R. (1) 562. 
deforestation has taken place. In similar lines, in M.C. Mehta $v$. Union of India, ${ }^{45}$ popularly known as the Kanpur tanneries case, the Supreme Court drawing a balance between right to development and right to environment said, "in cases of this nature this court may issue appropriate directions if it finds that the public nuisance or other wrongful act affecting or likely to affect public is being committed and the statutory authorities which are charged with the duty to prevent it are not taking adequate steps to rectify the grievance. For every breach of right there should be a remedy." The directions in this case were directed towards industries. In a latter case $^{46}$ the Supreme Court directed the Kanpur Nagar Mahapalika to take action under the provisions of the Uttar Pradesh Nagar Mahapalika Adhiniyam, 1959, or the relevant bye-laws made thereunder to prevent pollution of the water in the river Ganga by waste accumulated at the large number of dairies in Kanpur having 80,000 cattle. The court said that the dairies might either be shifted outside the city so that the waste at the dairies did not ultimately reach the river Ganga, or, in the alternative, the Mahapalika might arrange for the removal of the waste by motor vehicles, in which event the owners of the diaries could not claim any compensation. ${ }^{47}$ The court also ordered the Mahapalika to immediately take action to prevent collection of manure at private manure pits inside the city. The Kanpur Nagar Mahapalika should take immediate steps to increase the size of the sewers in the labour colonies, so that sewage might be carried smoothly through the sewerage system, and wherever sewerage line was not yet constructed, steps should be taken to lay it. 48 The court also directed "immediate action to be undertaken by the Kanpur Nagar Mahapalika to construct sufficient number of public latrines and urinals to prevent defecation by people on the open land. The proposal to levy any charge for use of such latrines and urinals shall be dropped as that would be a reason for poor people not to use the public latrines and urinals. The cost of maintenance of cleanliness of those latrines and

45 [1987] 4 S.C.C. 463.

${ }^{46}$ M.C. Mehta v. Union of India, 1988 S.C.R. (2) 530.

${ }^{47} \mathrm{Id}$. at $\$ 18$.

${ }^{48} \mathrm{Id}$. at $₫ 19$. 
urinals had to be borne by the Mahapalika." 49 The court further directed that the practice of throwing corpses and semi-burnt corpses into the river Ganga should be immediately brought to an end. Steps should be taken by the Kanpur Nagar Mahapalika and the police authorities to ensure that the dead bodies or half-burnt bodies were not thrown into the river Ganga. ${ }^{50}$ The Supreme Court said that "it was the duty of the central government to direct all the educational institutions throughout India to impart at least for one hour in a week lessons on the protection and improvement of the natural environment including forests, lakes, rivers and wild life in the first ten classes. The central government should get the text books written for the said purpose and distributed to the educational institutions free of cost. Training of teachers, who teach this subject, by the introduction of short term courses for such training shall also be considered. This should be done throughout India." 51

On similar lines, the Supreme Court laid down elaborate guidelines in the case of M.C. Mehta $v$. Union of India ${ }^{52}$ with regard to tanneries operating in Calcutta. In Vellore Citizens Welfare Forum v. Union of India ${ }^{53}$ the court observed that although the leather industry is a major foreign exchange earner for India and provided employment it does not mean that this industry has the right to destroy the ecology, degrade the environment or create health hazards. ${ }^{54}$ In this case the court ordered the central government to establish an authority to deal with the situation created by the tanneries and other polluting industries in the state of Tamil Nadu. This authority shall apply the precautionary principle and the polluter pays principle and identify the loss to the ecology, environment, individuals and families who have suffered because of the pollution, and then determine the compensation to reverse this

\footnotetext{
${ }^{49} \mathrm{Id}$. at $\boldsymbol{9} 20$.

${ }^{50} \mathrm{Id}$. at $₫ 22$.

${ }^{51} \mathrm{Id}$. at $\boldsymbol{\|} 24$.

52 (1997) 2 S.C.C. 411.

53 A.I.R. 1996 S.C. 2715.

${ }^{54} \mathrm{Id}$. at 99 .
} 
environmental damage and compensate those who have suffered from the pollution. The Collector / District Magistrates shall collect and disburse this money. 55 The court also directed the Special Bench of the Madras High Court to monitor the implementation of its judgments. In Indian Council for Enviro-Legal Action v. Union of India ${ }^{56}$ the Supreme Court ordered the closure of all the plants and factories of Hindustan Agro Chemicals Limited and Jyoti Chemicals located in Bichhri village by giving credence to right to environment. In M.C. Mehta v. Kamal Nath ${ }^{57}$ the Supreme Court took up the matter suo moto and directed the closure of a motel on the basis of the principle of public trust doctrine. ${ }^{58}$ In M.C. Mehta $v$. Union of India, ${ }^{59}$ popularly known as the oleum gas leak case, the Supreme Court said that "we cannot possibly adopt a policy of not having any chemical or other hazardous industry merely because they pose hazard or risk to the community. Industries, even if hazardous, have to be set up since they are essential for economic development and for advancement of well being of the people. We can only hope to reduce the element of hazard or risk to the community by taking all necessary measures for locating such industries in a manner which would pose least risk or danger to the community and maximizing safety requirements in such industries." The court further directed the government of India to evolve a national policy for location of chemical and other hazardous industries in areas where population is scarce and there is little hazard or risk to the community, and when hazardous industries are located in such areas, every care must be taken to see that large human habitation does not grow around them.

While trying to keep a balance between the right to environment and the right to development, Supreme Court had time and again

${ }^{55} \mathrm{Id}$. at $\uparrow 27$.

561996 (3) S.C.C. 212.

57 1997(1) S.C.C. 388.

58 M.C. Mehta v. Kamal Nath, (1997) 1 S.C.C. 388 ("the state is the trustee of all natural resources which are by very nature meant for public use and enjoyment. Public at large is the beneficiary").

${ }^{59}$ A.I.R. 1987 S.C. 1086. 
faltered in its approach. The list of cases cited above show the proenvironmentalist approach of the Supreme Court. Whereas, in Narmada Bachao Andolan v. Union of India and Others, 60 where the dispute was regarding Sardar Sarovar Dam, the Supreme Court while negating the plea of the Petitioners said that "while protecting the rights of the people from being violated in any manner, utmost care has to be taken that the court does not transgress its jurisdiction. In our constitutional framework there is a fairly clear demarcation of powers of the organs of the government. ${ }^{61}$ The court has come down heavily whenever the executive has sought to impinge upon the court's jurisdiction. At the same time, in exercise of its enormous power the court should not be called upon to or undertake governmental duties or functions. The courts cannot run the government nor can the administration indulge in abuse or non-use of power and get away with it. The role of the higher judiciary under the Constitution casts on it a great obligation as the sentinel to defend the values of the Constitution and the rights of Indians. The courts must, therefore, act within their judicially permissible limitations to uphold the rule of law and harness their power in public interest. It is precisely for this reason that it has been consistently held by this court that in matters of policy the court will not interfere. When there is a valid law requiring the government to act in a particular manner the court ought not to, without striking down the law, give any direction which is not in accordance with law. In other words, the court itself is not above the law. ${ }^{62}$ In respect of public projects and policies which are initiated by the government the courts should not become an approval authority. Normally such decisions are taken by the government after due care and consideration. In a democracy welfare of the people at large, and not merely of a small section of the society, has to be the concern of a responsible government. 63 If a considered policy decision has been taken, which is not in conflict with any law or is not mala fide, it will not

\footnotetext{
60 A.I.R. 2000 S.C. 3751.

${ }^{61} \mathrm{Id}$. at 763.

${ }^{62}$ Id. at 3857.

${ }^{63}$ Id. at $\$ 260$.
} 
be in a public interest to require the court to go into and investigate those areas which are the functions of the executive. For any project which is approved after due deliberation the court should refrain from being asked to review the decision. When the government takes a policy decision it is then not the function of the court to go into the matter afresh and, in a way, sit in appeal over such a policy decision." 64 The court in the said case only issued some directions for relief and rehabilitation. In Banwasi Sewa Ashram v. State of Uttar Pradesh 65 the court observed that "indisputably, forests are a much wanted national asset. On account of the depletion of forest, ecology has been disturbed and climate has undergone a major change and rains have become scanty. These have long-term adverse effects on national economy as also on the living process. At the same time, we cannot lose sight of the fact that for industrial growth and for providing improved living facilities, there is great demand in this country for electric energy. In fact, for quite some time the entire country in general and specific parts thereof, in particular, have suffered a tremendous setback in industrial activity for want of energy. A scheme to generate electricity, therefore, is equally of national importance and cannot be deferred." 66 The court was further moved in this case to lay down some directions for setting up a thermal plant at the disputed area. In Dahanu Taluka Environment Protection Group and Another v. Bombay Suburban Electricity Supply Company Limited 67 the Supreme Court said "it is sufficient to observe that it is primarily for the governments concerned to consider the importance of public projects for the betterment of the conditions of living of the people on the one hand and the necessity for preservation of social and ecological balances, avoidance of deforestation and maintenance of purity of the atmosphere and water free from pollution on the other in the light of various factual, technical and other aspects that may be brought to its notice by various bodies of laymen, experts and public workers and strike a just balance between these two conflicting

${ }^{64} I d$. at 9234 .

${ }^{65}$ A.I.R. 1987 S.C. 374.

${ }^{66} \mathrm{Id}$. at 376 .

67 (1991) 2 S.C.C. 539. 
objectives. The court's role is restricted to examine whether the government has taken into account all relevant aspects and has neither ignored or overlooked any material considerations nor been influenced by extraneous or immaterial considerations in arriving at its final decision." In Tehri Bandh Virodhi Sangharsh Samiti and Others $v$. the State of U.P. and Others ${ }^{68}$ the Supreme Court said that it lacks capability to adjudicate on the matters of technical nature and can only intervene where the government has failed to take adequate safety measures. In the second round of legal action 69 connected to the safety and environmental aspects of Tehri Dam, the Supreme Court said that "the courts have a duty to see that while making a decision, no law is violated and people's fundamental rights as guaranteed under the Constitution are not transgressed upon except to the extent permissible under the Constitution. When a law has been enacted in relation to the protection of environment and such law is being given effect to and there is no challenge to such law, the duty of the courts would be to see that the government and other respondents act in accordance with law and there is no other obligation for the court to examine further in the matter." These observations throw light as to how the right to development is in the conflict with the right to environment.

The Supreme Court has also taken cognizance of the concept of sustainable development in Vellore Citizen's Welfare Forum v. Union of India.70 The court in this case said that "though the leather industry is of vital importance to the country as it generates foreign exchange and provides employment avenues, it has no right to destroy the ecology. The traditional concept that development and ecology are opposed to each other is no longer acceptable. Sustainable development is the answer. Sustainable development has come to be accepted as a viable concept to eradicate poverty and improve the quality of human life while living within the carrying capacity of the supporting ecosystems." Sustainable development means the type or extent of development that can

681992 S.C.C. Supp. (1) 44.

${ }^{69}$ N.D. Jayal and Anr. v. Union of India, (2004) 9 S.C.C. 362.

70 (1996) 5 S.C.C. 647. 
take place and which can be sustained by nature/ecology with or without mitigation. The required standard now is that the risk of harm to the environment or to human health is to be decided in public interest, according to reasonable person test. ${ }^{71}$

It is pertinent to note that in all the above cited cases, the court has issued directions and laid down guidelines for the government. Judicial activism shown by the judiciary in maintaining a balance between the clash of titans is uncalled for and denotes the usurpation of power by the judiciary. ${ }^{72}$

\section{Denouement}

Development is a holistic concept. Indian Constitution, burdened with the task of uplifting the morals of the society, imbibing the ethos of the freedom struggle, has provided for various aspects of development under the visage of Directive Principles of the State Policy. The Directives provide for measures to build a society on the principles of fundamental freedoms guaranteed under the Constitution of India. Replete with socio-economic rights, which form the building blocks for the envisaged India, the Directives create a bounden duty on the government to take measures for achieving the set goals. Bringing the realization of such rights under the protection afforded to the fundamental rights, not only negates the essence of these rights, but also the import and meaning of such rights. ${ }^{73}$ Though, overwhelming activism shown by the judiciary can take shelter under the guardianship of

${ }^{71}$ M.C. Mehta v. Union of India, (2004) 12 S.C.C. 118.

72 Fali S. Nariman, R. B. Datar Memorial Lecture, Lawyers Update: Fifty Years of the Supreme Court - A Balance Sheet of Performance (JulyDecember 1999) ("too much reliance by the Supreme Court on Article 21 and its extensive extension by judicial extrapolation has given rise to the criticism that all sorts of goodness so derived as right from Article 21 are only euphoric - they simply cannot be enforced").

73 PARL. DEB., LOK Sabha (Part II) (1951) Col. 8822 ("the Directive principles of State Policy represent a dynamic move towards certain objective. The Fundamental rights represent something static, to preserve certain rights which exist. Both again are right. But somehow and sometime it might so happen that dynamic movement and that static standstill do not quite fit into each other"). 
environmentalist, on a deep perusal, it fails to satisfy the mandate of the Constitution. ${ }^{74}$

74 Swami Shraddananda v. State of Karnataka, (2007) 12 S.C.C. 288 ("the court cannot amend the constitution by judicial verdict or legislate or amend the law by process of interpretation"). 